\title{
Competitive Ability of Canola Hybrids with Weeds ${ }^{1}$
}

\author{
Habilidade Competitiva de Híbridos de Canola com Plantas Daninhas
}

\begin{abstract}
GALON, L. ${ }^{2}$, AGAZZI, L.R. ${ }^{2}$, VARGAS, L. ${ }^{3}$, NONEMACHER, F. ${ }^{2}$, BASSO, F.J.M. ${ }^{2}$, PERIN, G.F. ${ }^{2}$, FERNANDES, F.F. ${ }^{2}$, FORTE, C.T..$^{2}$, ROCHA, A.A. ${ }^{3}$, TREVISOL, R. ${ }^{2}$, and WINTER, F.L. ${ }^{2}$
\end{abstract}

\begin{abstract}
The objective of the study was to assess the relative competitive ability of canola hybrids in the presence of turnip (Raphanus sativus) and ryegrass (Lolium multiflorum) in different ratios of plants in the mixture. The experiments were conducted in a greenhouse, in a completely randomized design with four replications. Treatments were arranged in ratios of canola against turnip or ryegrass: 100:0, 75:25, 50:50, 25:75 and 0:100. Competitive analysis of the species was accomplished by means of diagrams usually applied to replacement series and also by the relative competitiveness indices. Fifty days after the emergence of the species, measurements of leaf area and shoot dry mass were performed. There was a competition between canola hybrids and weeds, with reduction for all variables. There was a differential competitive ability among canola hybrids in the presence of turnip and/or ryegrass. Canola hybrid Hyola 433 was more competitive in the presence of turnip than Hyola 61, 76 and $571 \mathrm{CL}$. Hyola 61, 76, 433 and $571 \mathrm{CL}$ do not differ in terms of competition ability when growing with ryegrass.
\end{abstract}

Keywords: Brassica napus, Raphanus sp., Lolium multiflorum.

RESUMO - Objetivou-se com este trabalho avaliar a habilidade competitiva relativa de híbridos de canola na presença de biótipos de nabo (Raphanus sativus) e de azevém (Lolium multiflorum), em diferentes proporções de plantas na associação. Os experimentos foram instalados em casa de vegetação, no delineamento experimental completamente casualizado com quatro repetições. Os tratamentos foram arranjados em proporções de plantas de canola, nabo e/ ou de azevém: 100:0, 75:25, 50:50, 25:75 e 0:100. A análise da competitividade das espécies foi efetuada por meio de diagramas aplicados a experimentos substitutivos e também pelos indices de competitividade relativa. Aos 50 dias após a emergência das espécies, efetuou-se a aferição da área foliar e da massa seca da parte aérea das plantas. Ocorreu competição entre os híbridos de canola e as plantas daninhas, provocando reduções das variáveis avaliadas. Foi observada diferenciação de habilidade competitiva entre os híbridos de canola quando na presença do nabo e/ ou do azevém. O híbrido de canola Hyola 433 foi mais competitivo na presença do nabo em relação a Hyola 61, Hyola 76 e Hyola 571 CL. Os híbridos de canola Hyola 61, Hyola 76, Hyola 433 e Hyola 571 CL não demonstraram diferenciação na competição ao serem associados com o azevém.

Palavras-chave: Brassica napus, Raphanus sp., Lolium multiflorum.

\section{INTRODUCTION}

Canola (Brassica napus) becomes an important crop for Brazilian agriculture due to having its grains used as a source of vegetable oil for biodiesel production (Tan et al., 2009), besides having an allelopathic potential on seedlings germination and development. Another highlight is its use as a cover crop and also as an alternative to the crop rotation system with maize, soybeans and beans grown in the summer.

1 Recebido para publicação em 12.3.2015 e aprovado em 8.6.2015.

2 Universidade Federal da Fronteira Sul (UFFS), Erechim-RS, Brasil, <leandro.galon@uffs.edu.br>; ${ }^{2}$ Embrapa Trigo, Passo FundoRS, Brasil; ${ }^{3}$ Faculdade IDEAU, Getúlio Vargas-RS, Brasil. 
The Brazilian production of canola is concentrated in the South, and the state of Rio Grande do Sul (RS) accounts for $77.41 \%$ of the total grain produced in the country, with an average yield of $1,287 \mathrm{~kg} \mathrm{ha}^{-1}$, which is $11.33 \%$ lower than the national average (Conab, 2015).

Among the factors that significantly affect the productivity of canola grains, especially in the RS, the interference caused by weeds stands out, which, if not properly controlled, can compromise, besides grain yield, its quality. Among the weeds that infest canola, turnip (Raphanus sativus and $R$. raphanistrum) and ryegrass (Lolium multiflorum) stand out; they are highly competitive for water resources, light, $\mathrm{CO}_{2}$ and nutrients, and, in many cases, are resistant to herbicides inhibitors of ALS (acetolactate synthase enzyme (also known as acetohydroxy acid synthase, or AHAS), ACCase (Acetyl-CoA carboxylase (ACC)) and EPSPs (5-enolpyruvylshikimate-3-phosphate). This fact has become more serious in recent years due to their use as ground cover plants (Lamego et al., 2013) and in the production of grains/seeds and/or pasture for feed.

Incentives to canola harvest in Brazil in recent decades have made research agencies increase the work related to tillage and cultivation practices pertaining to this crop. However, technical and scientific information for canola tillage in the country is still incipient (Bandeira et al., 2013).

Investigations on the competitiveness of crops with weeds allow the development of strategies for their control, because they can define the characteristics that confer greater competitive ability to crops at the expense of weeds. The determination of the competitive interactions between crops and weeds requires appropriate experimental designs and analysis methods, and conventional substitute experiments are commonly used to clarify these relationships (Roush et al., 1989; Bianchi et al., 2006; Agostinetto et al., 2013).

In experiments conducted in substitutive series, usually crops show greater competitive ability than the weeds. According to Agostinetto et al. (2013), the increased crop competitiveness when infested by a weed species can be related to higher capacity of environmental resources seizure, less need to use the resource or the anticipated emergence in relation to other species and population present.

In this context, the identification of canola hybrids which have higher competitive ability with weeds infesting this crop needs to be done and disseminated since thus it is possible to handle the crop with less use of herbicides and thereby cause less environmental impacts, reducing costs to the farmer. It also stands out that for the canola crop in competition with turnip and/or ryegrass no studies were found in the literature that have quantified the competitive ability of canola hybrids infested by these weeds. Many studies using the substitutive method show that there are differences in the competitive ability of other crops such as; rice versus red rice, gulf cockspur grass and Aeschynomene denticulata (common names vary regionally) (Fleck et al., 2008; Agostinetto et al., 2008; Galon et al., 2015), soybeans versus turnip, plantain signalgrass and cockspur (or cockspur grass), barnyard millet, Japanese millet, water grass, common barnyard grass, or simply "barnyard grass") (Bianchi et al., 2006; Agostinetto et al., 2009, 2013), barley versus ryegrass (Galon et al., 2011), among others.

Given the above, the aim of this study is to assess the relative competitive ability of canola hybrids in the presence of turnip (R. sativus) and ryegrass (L. multiflorum) biotypes in different plants ratios in the association.

\section{MATERIALS AND METHODS}

The experiments were conducted in a greenhouse between May and August 2014. The experimental units consisted of plastic pots with a capacity of $8 \mathrm{dm}^{3}$ filled with soil originating from an agriculture area, characterized by humic ferric aluminum red oxisol (Embrapa, 2013). The soil correction was done according to the technical recommendations for growing canola for both preliminary and final tests. The experimental design adopted, in all experiments, was the completely randomized one, with four replications. The competitive ones tested included canola hybrids Hyola 61, Hyola 76, 
Hyola 433 and Hyola 571 CL (Clearfield $^{\circledR}$ ), which competed with turnip ( $R$. sativus) and ryegrass (L. multiflorum) biotypes.

Preliminary experiments were performed in additive series for canola and turnip and/or ryegrass in monocultures, in order to determine the plant population in which the final yield becomes constant. For this, populations of $1,2,4,8,16,24,32,40,48,56$ and 64 plants pot ${ }^{-1}$ were used (equivalent to 25 , 49, 98, 196, 392, 587, 784, 980, 1,176, 1,372 and 1,568 plants $\mathrm{m}^{-2}$ ). At 50 days after the emergence of the species, the shoots of canola, turnip and/or ryegrass were collected to determine the shoots dry mass (DM), which is quantified by weighing after being dried in a greenhouse with forced air circulation at a temperature of $65 \pm 5{ }^{\circ} \mathrm{C}$ until reaching constant mass. By means of the average values of the species DM, DM constant yield was obtained with populations of 20 plants pot ${ }^{-1}$ for all canola hybrids, turnip and/or ryegrass biotypes, which amounted to 465 plants $\mathrm{m}^{-2}$ (data not shown).

Eight other experiments were conducted to assess the competitive ability of canola hybrids Hyola 61, Hyola 76, Hyola 433 and Hyola $571 \mathrm{CL}$ with the plants of turnip and/or ryegrass (competitors), all conducted by the replacement series method in the different combinations of canola hybrids and weed biotypes, ranging the relative ratios of plants pot $^{-1}(20: 0,15: 5,10: 10,5: 15$ and 0:20) and keeping constant the total plant population (20 plants pot $\left.{ }^{-1}\right)$. To establish the desired populations in each treatment and achieve seedlings uniformity, seeds were sown in trays beforehand, and later transplanted to pots.

At 50 days after the emergence of the species, the measurement of the leaf area (LA) and shoots dry mass (DM) was performed for canola and the competing ones. This time was chosen because it is the stage where both canola hybrids as the weeds were entering the reproductive stage. For determination of LA, a portable leaf area meter model CI-203 BioScence was used, quantifying the variable in all plants in each treatment. After determining the LA, the plants were placed in paper bags and subjected to drying in forced air circulation oven at a temperature of $65 \pm 5{ }^{\circ} \mathrm{C}$ until constant weight was obtained.

The data were analyzed by the method of variation graphical analysis or relative productivity (Roush et al., 1989; Cousens, 1991; Bianchi et al., 2006). This procedure, also known as a conventional method to substitutive experiments, involves the construction of a diagram based on the relative (RY) and total (TRY) yield or variations. When the RY result is a straight line, it means that the species skills are equivalent. If the RY results in a concave line, this indicates that there is a loss in growth of one or both species. On the contrary, if the RY shows a convex line, there is an advantage in growth of one or both species. When the TRY is equal to unit 1 (straight line), there is a competition for the same resources; if it is greater than 1 (convex line), the competition is avoided. If the TRP is less than 1 (concave line), there is mutual impairment of growth (Cousens, 1991).

The relative competitiveness (RC), the relative clustering coefficient $(\mathrm{K})$ and aggression (A) indexes were calculated. The RC represents the comparative growth of canola hybrids (X) in relation to the competitors turnip and/or ryegrass $(\mathrm{Y})$; $\mathrm{K}$ indicates the relative dominance of one species over another; and A points which species is more aggressive. Thus, the $\mathrm{RC}, \mathrm{K}$ and $\mathrm{A}$ indices indicate which species is more competitive and its joint interpretation more safely points to competitiveness of the species (Cousens, 1991). Canola hybrids X are more competitive than turnip and/or ryegrass $\mathrm{Y}$ when $\mathrm{RC}>1, \mathrm{Kx}>\mathrm{Ky}$ and $\mathrm{A}>0$; on the other hand, turnip and/or ryegrass $\mathrm{Y}$ are more competitive than canola hybrids $\mathrm{X}$ when $\mathrm{RC}<1$, $\mathrm{Kx}<\mathrm{Ky}$ and $\mathrm{A}<0$ (Hoffman \& Buhler, 2002). To calculate these rates, ratios 50:50 of the species involved in the experiment (canola versus turnip and/or ryegrass) were used or populations of 10:10 plants/plant, using the equations: $\mathrm{RC}=\mathrm{RYx} / \mathrm{RYy} ; \mathrm{Kx}=\mathrm{RYx} /(1-\mathrm{RYx})$; $\mathrm{Ky}=\mathrm{RYy} /(1-\mathrm{RYy}) ; \mathrm{A}=\mathrm{RYx}-\mathrm{RYy}$, according to Cousens \& O’Neill (1993).

The yield or relative variation statistical analysis procedure included the calculation of the differences for the RY values (DPR) obtained in ratios of 25,50 and $75 \%$ in relation to the values belonging to the hypothetical straight 
line in the respective ratios, which are: 0.25 , 0.50 and 0.75 for RY (Bianchi et al., 2006; Fleck et al., 2008). t-test was used to test the differences related to indexes DPR, TRY, RC, $\mathrm{K}$ and $\mathrm{A}$ (Roush et al., 1989). It was considered as a null hypothesis to test the differences of DPR and A that the means were equal to zero $(\mathrm{Ho}=0)$; for TRY and RC that the means were equal to $1(\mathrm{Ho}=1)$; and for $\mathrm{K}$ that the means of the differences between $\mathrm{Kx}$ and $\mathrm{Ky}$ were equal to zero $[\mathrm{Ho}=(\mathrm{Kx}-\mathrm{Ky})=0]$. The criterion to consider the RY and TRY curves that are different from the hypothetical straight lines was that, at least in two ratios, significant differences occurred by t-test (Bianchi et al., 2006). Similarly, for RC, K and A indices, the existence of differences in competitiveness was considered when, at least in two of them, there was a significant difference by t-test.

The results obtained for LA and DM, expressed as average values per treatment, were subjected to analysis of variance by the F-test; when this one was significant, the treatment means were compared by Dunnett's test, considering monocultures as controls in these comparisons. In all statistical analyses performed, $\mathrm{p}<0.05$ was adopted.

\section{RESULTS AND DISCUSSION}

In general, it was possible to see, when performing the variance analysis, that significant interactions occurred between the ratios of canola hybrids and weeds, turnip and/ or ryegrass. The graphs results demonstrate, for combinations of plants of canola hybrids Hyola 61, Hyola 76, Hyola 433 and Hyola 571 CL with turnip and/or ryegrass (competing) biotypes, that the four hybrids showed similarities in the competition with weeds, and there were significant differences for LA and $\mathrm{DM}$ variables in the tested plants ratios. With respect to TRY, there were significant differences among expected and estimated values for all variables studied, and these presented average values near or greater than 1 only for variable LA when canola hybrid Hyola 76 competed with turnip in the 25:75 ratio, while the others showed values of less than 1 in all combinations (Figures 1, 2, 3 and 4).

In general, the presence of concave lines in all the simulations for both LA and DM variables was observed, indicating that there was competition for the same environmental resources, with mutual damage for the growth of crop and competing turnip and/or ryegrass (Figures 1, 2, 3 and 4). In all simulations assessed, the species did not differ for the two variables studied (Figures 1, 2, 3 and 4), except for LA in two situations: first, when hybrid Hyola 76, in ratio 25:75 in the presence of turnip, the weed has performed more competitive than canola (Figure 1); and in the second, when Hyola 433 was more competitive than ryegrass plants in all plant ratios (Figure 2). Thus, it is not possible to establish that there was increased competition from one or another species because, in general, for all tested variables there was a similar behavior in competition for environmental resources. In general, canola hybrids Hyola 61, Hyola 76, Hyola 433 and Hyola 571 CL grew faster than turnip and/or ryegrass in all tested plants ratios (Figures 1, 2, 3 and 4), however, they contributed very little to TRY.

The probable cause for canola having higher growth than weeds and having been more competitive than these may be related to the population of plants that competed with the crop, since the weeds showed greater competitive ability when in high population densities and not individually (Rigoli et al., 2008; Agostinetto et al., 2013; Galon et al., 2015). It is noteworthy that, in substitutive experiments, there is little evidence of having qualitative changes due to population increase, i.e., the dominance of one species over another rarely changes with the change of the population (Cousens \& O'Neill, 1993). The results observed in this study are corroborated by the ones verified by Agostinetto et al. (2008), Fleck et al. (2008), Agostinetto et al. (2009) and Galon et al. (2011, 2015). However, conflicting results have been verified by Agostinetto et al. (2013), who found different behavior when rice and soybeans competed with cockspur, and the crops, in this case, were more competitive than the weeds, therefore occurring differences between species in competition.

RY differences of canola hybrids were observed when competing with turnip and/or ryegrass in relation to the respective hypothetical straight lines in at least two 

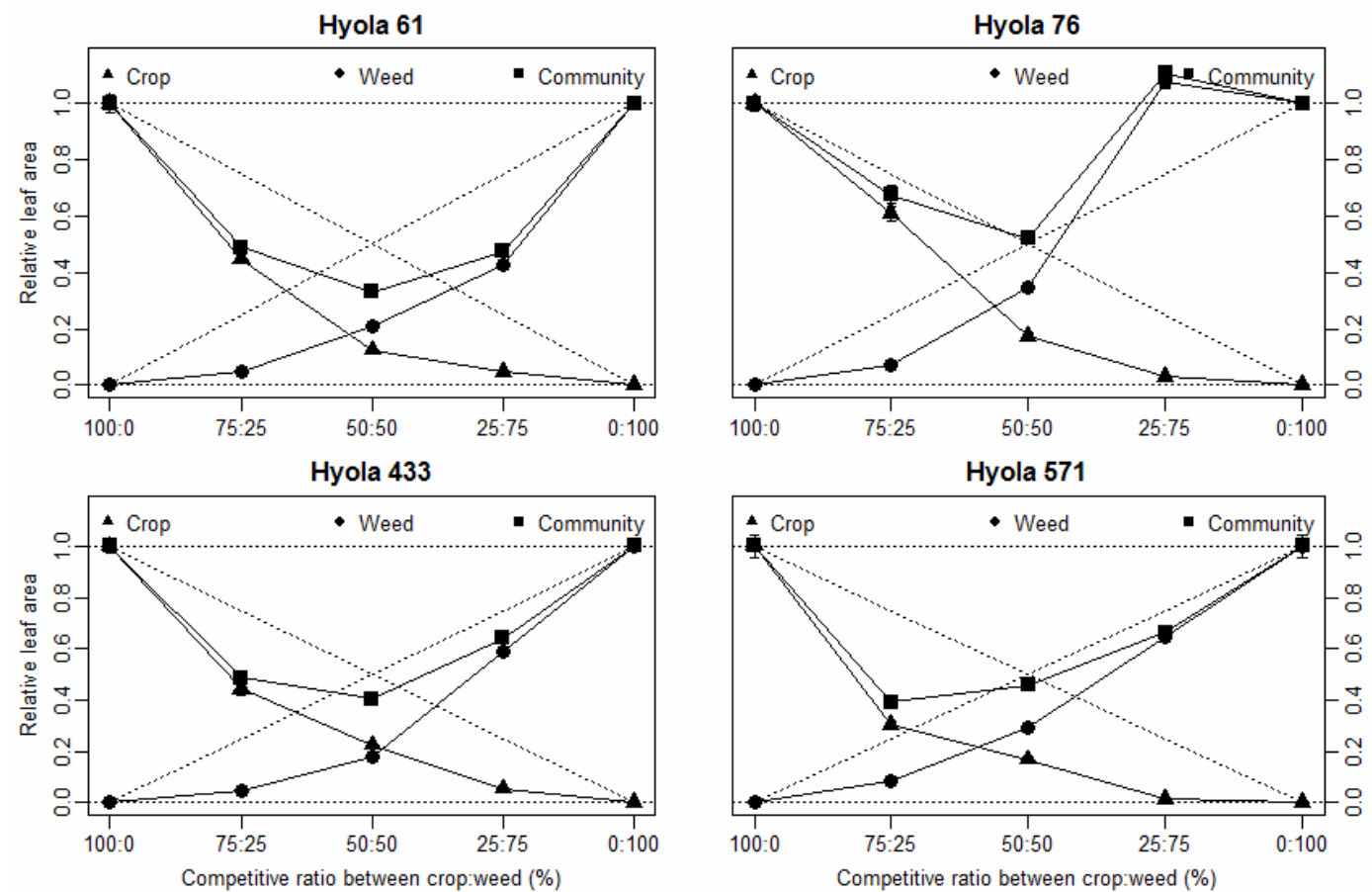

Figure 1 - Relative yield (RY) for the relative leaf area of canola $(\mathbf{\Delta})$ and turnip $(\bullet)$ and the total relative yield (TRY) of the community ( $\mathbf{\square})$ due to the plants ratio (canola:turnip). Dashed lines represent the expected values in the absence of competition, and solid lines represent the observed values when the species competed in different plants ratios. Standard errors between repetitions of each observed value are presented. UFFS, Erechim, RS, 2014.
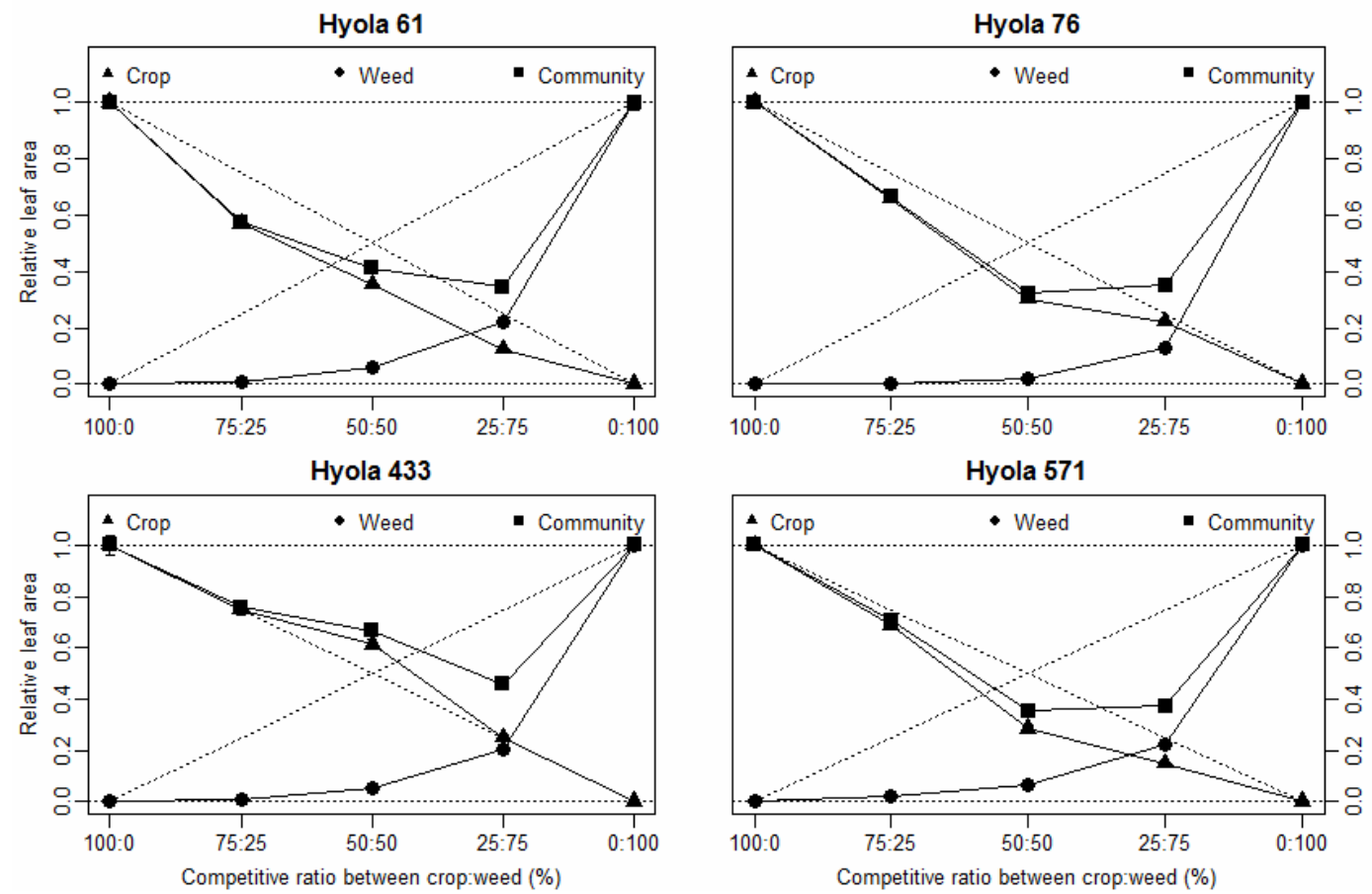

Figure 2 - Relative yield (RY) for the relative leaf area of canola plants $(\boldsymbol{\Delta})$ and ryegrass $(\bullet)$ and total relative yield (TRY) of the community ( $\mathbf{0})$ due to the plants ratio (canola:ryegrass). Dashed lines represent the expected values in the absence of competition, and solid lines represent the observed values when the species competed in different plants ratios. Standard errors between repetitions of each observed value are presented. UFFS, Erechim, RS, 2014. 

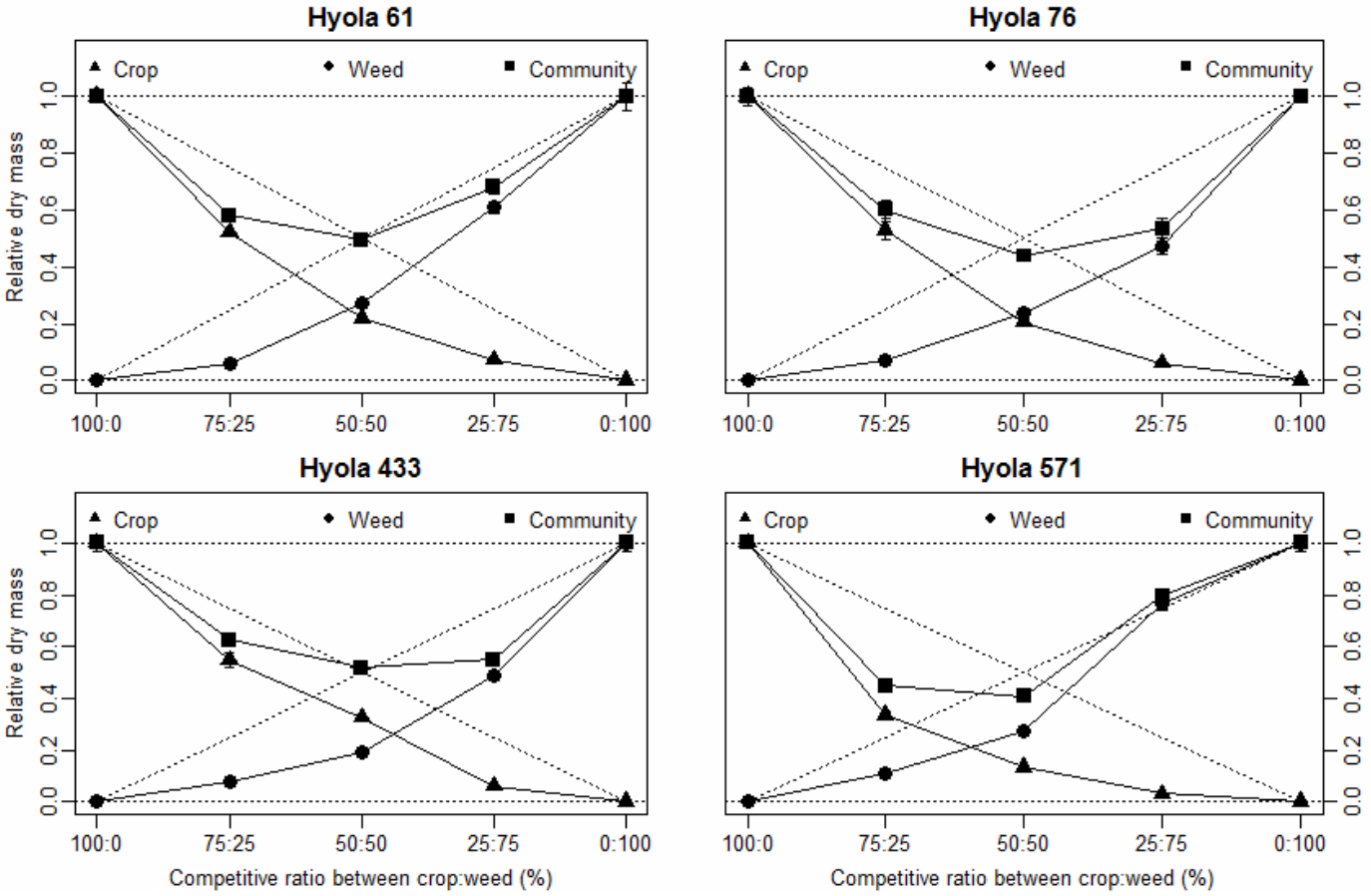

Figure 3 - Relative yield (RY) for the relative dry matter of canola $(\boldsymbol{\Delta})$ and turnip $(\bullet)$ and the total relative yield (TRY) of the community ( $\mathbf{\square})$ due to the plants ratio (canola:turnip). Dashed lines represent the expected values in the absence of competition, and solid lines represent the observed values when the species competed in different plants ratios. Standard errors between repetitions of each observed value are presented. UFFS, Erechim, RS, 2014.
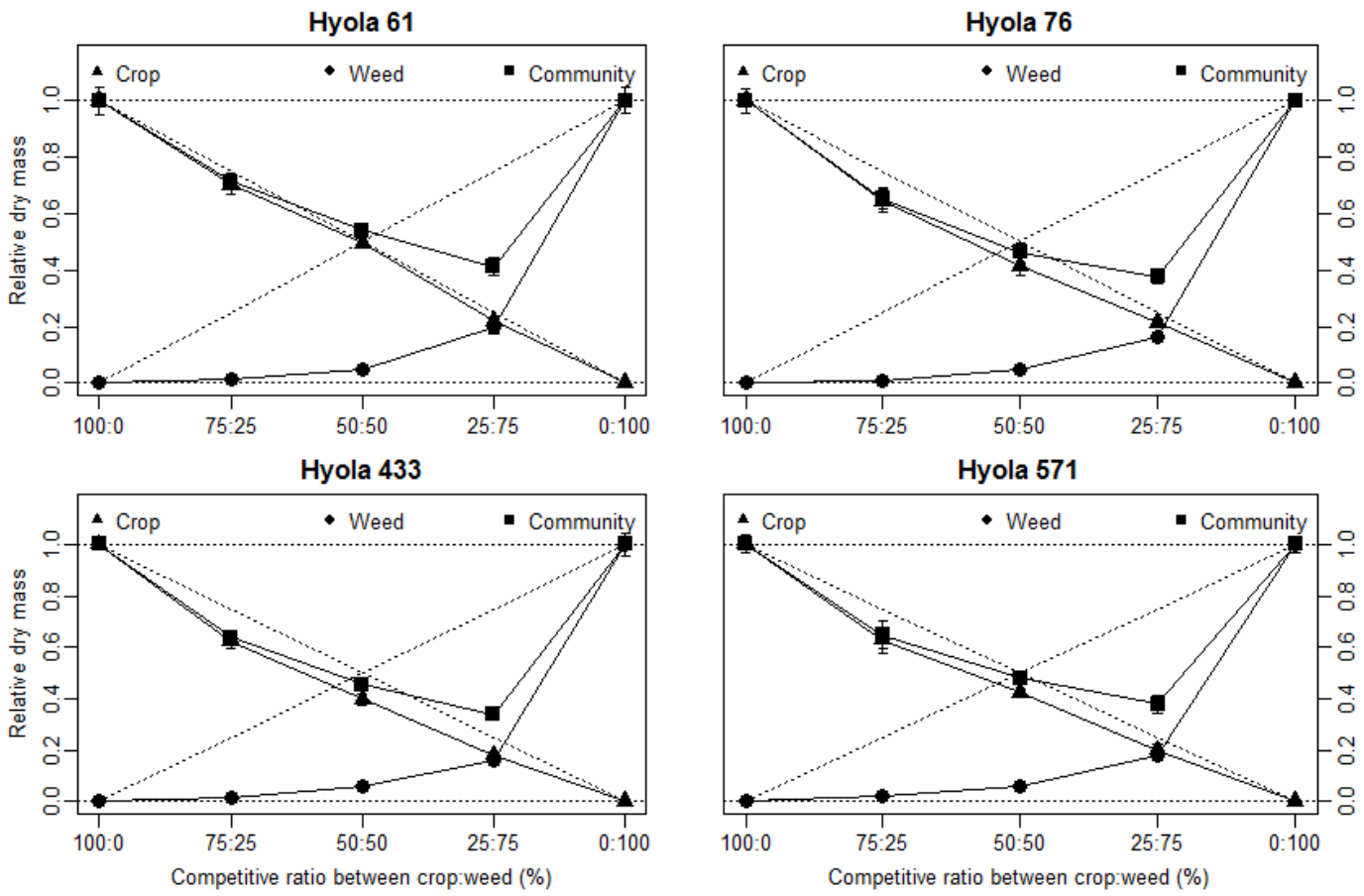

Figure 4 - Relative yield (RY) for the relative dry matter of canola $(\boldsymbol{\Delta})$ and ryegrass $(\bullet)$ and the total relative yield (TRY) of the community ( $\mathbf{\square})$ due to the plants ratio (canola:ryegrass). Dashed lines represent the expected values in the absence of competition, and solid lines represent the observed values when the species competed in different plants ratios. Standard errors between repetitions of each observed value are presented. UFFS, Erechim, RS, 2014. 
plants ratios, according to results expressed by standard errors in Figures 1, 2, 3 and 4. According to Bianchi et al. (2006), so that there is significance, at least two plants ratios should differ, and differences were found between the studied and expected straight lines in all tested variables and in all plants ratios. In the present study, mutual losses to the crop and to the weeds were found on the species growth in the community - in particular, canola. It should be noted, however, that weeds in agricultural areas normally appear in populations exceeding the cultivated plants, and in the majority of situations they are considered more competitive in the use of resources available in the environment (Bianchi et al., 2006).
In general, the morphological variables LA and DM of canola hybrids Hyola 61, Hyola 76, Hyola 433 and Hyola 571 CL were reduced when competing with turnip and/or ryegrass in all associations analyzed, regardless of the plants ratio in the association (Tables 1 and 2). The higher the competitors ratio in association with the hybrids, the greater the damage to the crop variables. In turnip and ryegrass there was a reduction in the LA and DM when in an equal or smaller plant ratio, compared to canola hybrids.

Similar results to those found in this study were also observed by Bianchi et al. (2006), Fleck et al. (2008) and Agostinetto et al. (2013), when working with soybeans versus turnip,

Table 1 - Differences between plants associated or not of canola hybrids Hyola 61, Hyola 76, Hyola 433 and 571 Hyola and of turnip for variables leaf area and dry weight of shoot, at 50 days after plant emergence. UFFS, Erechim, RS, 2014

\begin{tabular}{|c|c|c|c|c|}
\hline \multirow{3}{*}{$\begin{array}{c}\text { Plants ratio } \\
\text { Canola: turnip }\end{array}$} & \multicolumn{4}{|c|}{ Leaf area $\left(\mathrm{cm}^{2}\right.$ pot $\left.^{-1}\right)$} \\
\hline & \multicolumn{4}{|c|}{ Canola hybrids } \\
\hline & Hyola 61 & Hyola 76 & Hyola 433 & Hyola 571 \\
\hline $100: 0(\mathrm{~T})$ & 2329.34 & 1563.58 & 1799.07 & 2166.13 \\
\hline $75: 25$ & $1384.35^{*}$ & $1270.50 *$ & $1063.32 *$ & $879.76^{*}$ \\
\hline $50: 50$ & $574.03^{*}$ & $542.02 *$ & 814.49* & $729.72 *$ \\
\hline $25: 75$ & $431.62 *$ & $185.19 *$ & $395.77 *$ & 119.80* \\
\hline \multirow[t]{2}{*}{$\mathrm{CV}(\%)$} & 8.4 & 10.5 & 9.0 & 12.5 \\
\hline & \multicolumn{4}{|c|}{ Competing turnip } \\
\hline $100: 0(\mathrm{~T})$ & 2614.28 & 1177.63 & 2433.67 & 1453.48 \\
\hline $75: 25$ & 1489.57* & $1692.2^{*}$ & 1908.94* & $1258.55^{*}$ \\
\hline $50: 50$ & $1083.70 *$ & $818.27^{*}$ & $866.71^{*}$ & 841.73 \\
\hline $25: 75$ & $467.58 *$ & $320.6^{*}$ & 429.58* & 499.76 \\
\hline CV (\%) & 5.1 & 7.3 & 4.6 & 8.6 \\
\hline \multicolumn{5}{|c|}{ Shoot dry mass $\left(\mathrm{g} \mathrm{pot}^{-1}\right)$} \\
\hline & \multicolumn{4}{|c|}{ Canola hybrids } \\
\hline & Hyola 61 & Hyola 76 & Hyola 433 & Hyola 571 \\
\hline $100: 0(\mathrm{~T})$ & 16.73 & 14.89 & 22.12 & 23.44 \\
\hline $75: 25$ & 11.59* & $10.52^{*}$ & $16.16^{*}$ & $10.49 *$ \\
\hline $50: 50$ & $7.37 *$ & $6.07^{*}$ & $14.43^{*}$ & $6.23 *$ \\
\hline $25: 75$ & $4.87 *$ & $3.60 *$ & $5.51 *$ & $2.88 *$ \\
\hline \multirow[t]{2}{*}{ CV (\%) } & 7.0 & 10.8 & 9.2 & 7.1 \\
\hline & \multicolumn{4}{|c|}{ Competing turnip } \\
\hline $0: 100(\mathrm{~T})$ & 23.53 & 17.74 & 24.52 & 22.00 \\
\hline $25: 75$ & 19.13* & $11.21 *$ & $15.95 *$ & 22.46 \\
\hline $50: 50$ & $12.89 *$ & $8.33 *$ & $9.36 *$ & $12.05 *$ \\
\hline $75: 25$ & $5.62 *$ & 5.07 & $7.78 *$ & $9.85 *$ \\
\hline CV (\%) & 11.5 & 8.8 & 9.1 & 8.3 \\
\hline
\end{tabular}

* Means differ from the control (T) by the Dunnett test ( $\mathrm{p} \leq 0.05$ ). 
Table 2 - Differences between plants associated or not of canola hybrids Hyola 61, Hyola 76, Hyola 433 and 571 Hyola and of ryegrass for variables leaf area and dry weight of shoot, at 50 days after plant emergence. UFFS, Erechim, RS, 2014

\begin{tabular}{|c|c|c|c|c|}
\hline \multirow{3}{*}{$\begin{array}{c}\text { Plants ratio } \\
\text { Canola: ryegrass }\end{array}$} & \multicolumn{4}{|c|}{ Leaf area $\left(\mathrm{cm}^{2}\right.$ pot $\left.^{-1}\right)$} \\
\hline & \multicolumn{4}{|c|}{ Canola hybrids } \\
\hline & Hyola 61 & Hyola 76 & Hyola 433 & Hyola 571 \\
\hline $100: 0(\mathrm{~T})$ & 3786.71 & 2277.77 & 2155.89 & 2103.68 \\
\hline $75: 25$ & $2874.45 *$ & $2002.00 *$ & 1761.37 & 1932.15 \\
\hline $50: 50$ & $2676.59 *$ & 1382.53* & 1760.96* & 1198.33* \\
\hline $25: 75$ & 1859.24* & 2017.77* & 1767.40 & 1244.80* \\
\hline \multirow[t]{2}{*}{ CV (\%) } & 3.1 & 4.7 & 7.6 & 6.8 \\
\hline & \multicolumn{4}{|c|}{ Competing ryegrass } \\
\hline $0: 100(\mathrm{~T})$ & 23757.99 & 31366.99 & 15145.26 & 16410.89 \\
\hline $25: 75$ & $7038.32 *$ & $5422.15^{*}$ & 4177.43* & 4937.06* \\
\hline $50: 50$ & 2782.33* & 1249.19* & 1618.80* & $2246.83 *$ \\
\hline $75: 25$ & 731.04* & 553.95* & 528.48* & $1226.45^{*}$ \\
\hline $\mathrm{CV}(\%)$ & 8.8 & 5.4 & 3.7 & 3.4 \\
\hline \multicolumn{5}{|c|}{ Shoot dry mass (g pot $\left.{ }^{-1}\right)$} \\
\hline & \multicolumn{4}{|c|}{ Canola hybrids } \\
\hline & Hyola 61 & Hyola 76 & Hyola 433 & Hyola 571 \\
\hline $100: 0(\mathrm{~T})$ & 23.97 & 23.30 & 28.38 & 23.16 \\
\hline $75: 25$ & 22.40 & 20.04 & $23.57 *$ & 19.40 \\
\hline $50: 50$ & 23.77 & 19.33 & $22.55 *$ & 19.64 \\
\hline $25: 75$ & 20.86 & 19.86 & $20.58 *$ & 18.51 \\
\hline \multirow[t]{2}{*}{ CV (\%) } & 10.1 & 12.9 & 8.2 & 15.3 \\
\hline & \multicolumn{4}{|c|}{ Competing ryegrass } \\
\hline $0: 100(\mathrm{~T})$ & 20.47 & 23.32 & 16.84 & 18.54 \\
\hline $25: 75$ & $5.31 *$ & $5.10 *$ & $3.57 *$ & $4.44 *$ \\
\hline $50: 50$ & $1.85^{*}$ & $2.25 *$ & $1.93 *$ & $2.13^{*}$ \\
\hline $75: 25$ & $1.14^{*}$ & $0.86^{*}$ & $0.96 *$ & $1.49 *$ \\
\hline $\mathrm{CV}(\%)$ & 17.8 & 8.3 & 15.5 & 12.4 \\
\hline
\end{tabular}

* Means differ from the control $(\mathrm{T})$ by the Dunnett test $(\mathrm{p} \leq 0.05)$.

rice versus red rice, and rice and soybean versus cockspur, respectively.

The results show for both LA and DM variables that the highest averages per crop plant or even of turnip and/or ryegrass were obtained when these were presented in smaller populations in association with all combinations. (Tables 1 and 2). When comparing the mean values of PA and DM of all canola hybrids involved in competition with turnip and/or ryegrass, in each plants ratio of the mixture $(25,50,75$ and $100 \%)$, it was observed that the competition among related species - the same family (canola versus turnip) was more harmful than the competition of species from different families
- canola versus ryegrass (Tables 1 and 2). Thus, competition in the same family of plants is more harmful than the competition among plants of different families. Results similar to these ones were observed by Agostinetto et al. (2013) when establishing that the competition among plants of the same family is more harmful than among plants from different families.

It was observed that LA and DM values of canola hybrids in ratios of each mixture $(75,50$ and $25 \%)$ when compared with monocultures $(100 \%)$, that the interspecific competition in all species involved in the association (canola versus turnip and/or canola versus ryegrass) was more harmful to 
the growth of species than competition among individuals (Tables 1 and 2). The results of this study are corroborated by the ones found by Bianchi et al. (2006), when assessing soybeans versus turnip; Fleck et al. (2008), studying rice versus red rice; Agostinetto et al. (2008), when working with rice versus gulf cockspur grass; and Agostinetto et al. (2013), when researching rice and soybeans versus cockspur. The competition quantitatively and qualitatively affects the production because it modifies the utilization efficiency of environmental resources such as water, light, $\mathrm{CO}_{2}$ and nutrients (Bianchi et al., 2006), settling between the crop and plants of other species found on site. It is also noteworthy that in a community of plants there is benefit in the competition for resources for those which are established first, or for intrinsic characteristics of each cultivar or hybrid regarding the competitive ability (height, growth rate, number of tillers, among others).

By sowing the crops in association with weeds with variation in the plants ratio, usually the crops present an advantage regarding the relative yield, thus demonstrating that the intraspecific competition exceeds the interspecific one (Woldeamlak et al., 2001). Similar results occurred when wheat grew with ryegrass (Rigoli et al., 2008); barley, when infested by ryegrass (Galon et al., 2011); and rice, in the presence of Aeschynomene denticulata (common names vary regionally) (Galon et al., 2015).

Regarding the relative competitiveness index $(\mathrm{RC})$, there was greater growth and competitiveness $(\mathrm{K})$ and aggression coefficients only for canola hybrid Hyola 433, for variables LA and DM when competing with turnip (Table 3). In this table, it was observed that the

Table 3 - Competitiveness indices among canola hybrids with weeds turnip and ryegrass competing in equal ratios of plants (50:50), expressed as relative competitiveness (RC), relative clustering coefficients (K) and aggression (A) obtained in experiments conducted in substitutive series, at 50 days after plant emergence. UFFS, Erechim, RS, 2014

\begin{tabular}{|c|c|c|c|c|}
\hline Variable & $\mathrm{RC}$ & Kx (canola) & Ky (turnip/ryegrass) & A \\
\hline \multicolumn{5}{|c|}{ Leaf area } \\
\hline Hyola 61 versus turnip & $0.60( \pm 0.03)^{*}$ & $0.14( \pm 0.00)^{*}$ & $0.26( \pm 0.01)$ & $-0.08( \pm 0.01)^{*}$ \\
\hline Hyola 76 versus turnip & $0.50( \pm 0.05)^{*}$ & $0.21( \pm 0.02)^{*}$ & $0.54( \pm 0.05)$ & $-0.17( \pm 0.03)^{*}$ \\
\hline Hyola 433 versus turnip & $1.27( \pm 0.06)$ & $0.29( \pm 0.01)^{*}$ & $0.22( \pm 0.01)$ & $0.05( \pm 0.01)^{*}$ \\
\hline Hyola 571 versus turnip & $0.58( \pm 0.03)^{*}$ & $0.20( \pm 0.01)^{*}$ & $0.41( \pm 0.01)$ & $-0.12( \pm 0.01)^{*}$ \\
\hline \multicolumn{5}{|c|}{ Shoot dry mass } \\
\hline Hyola 61 versus turnip & $0.81( \pm 0.06)$ & $0.28( \pm 0.02)$ & $0.38( \pm 0.03)$ & $-0.05( \pm 0.02)$ \\
\hline Hyola 76 versus turnip & $0.87( \pm 0.07)$ & $0.26( \pm 0.01)$ & $0.31( \pm 0.01)$ & $-0.03( \pm 0.02)$ \\
\hline Hyola 433 versus turnip & $1.73( \pm 0.09)^{*}$ & $0.49( \pm 0.03)^{*}$ & $0.24( \pm 0.02)$ & $0.14( \pm 0.01)^{*}$ \\
\hline Hyola 571 versus turnip & $0.49( \pm 0.03)^{*}$ & $0.15( \pm 0.01)^{*}$ & $0.38( \pm 0.02)$ & $-0.14( \pm 0.01)^{*}$ \\
\hline \multicolumn{5}{|c|}{ Leaf area } \\
\hline Hyola 61 versus ryegrass & $6.04( \pm 0.01)^{*}$ & $0.54( \pm 0.01)^{*}$ & $0.06( \pm 0.00)$ & $0.29( \pm 0.00)^{*}$ \\
\hline Hyola 76 versus ryegrass & $15.24( \pm 0.49) *$ & $0.44( \pm 0.02)^{*}$ & $0.02( \pm 0.00)$ & $0.28( \pm 0.01)^{*}$ \\
\hline Hyola 433 versus ryegrass & $11.51( \pm 0.69)^{*}$ & $1.59( \pm 0.12)^{*}$ & $0.06( \pm 0.00)$ & $0.56( \pm 0.02)^{*}$ \\
\hline Hyola 571 versus ryegrass & $4.16( \pm 0.21)^{*}$ & $0.40( \pm 0.03)^{*}$ & $0.07( \pm 0.00)$ & $0.22( \pm 0.01)^{*}$ \\
\hline \multicolumn{5}{|c|}{ Shoot dry mass } \\
\hline Hyola 61 versus ryegrass & $11.10( \pm 0.78)^{*}$ & $0.99( \pm 0.06)^{*}$ & $0.05( \pm 0.00)$ & $0.45( \pm 0.02) *$ \\
\hline Hyola 76 versus ryegrass & $8.81( \pm 0.74)^{*}$ & $0.72( \pm 0.09)^{*}$ & $0.05( \pm 0.01)$ & $0.37( \pm 0.03)^{*}$ \\
\hline Hyola 433 versus ryegrass & $7.29( \pm 1.27)^{*}$ & $0.66( \pm 0.06)^{*}$ & $0.06( \pm 0.01)$ & $0.34( \pm 0.03)^{*}$ \\
\hline Hyola 571 versus ryegrass & $7.57( \pm 0.86)^{*}$ & $0.74( \pm 0.05)^{*}$ & $0.06( \pm 0.01)$ & $0.37( \pm 0.02)^{*}$ \\
\hline
\end{tabular}

$\mathrm{RC}$ and A: t-test, being considered significant $\left(^{*}\right)$ when differing $(\mathrm{p} \leq 0.05)$ from 1 and 0 , respectively. Difference between $\mathrm{K}_{\mathrm{x}}$ and $\mathrm{K}_{\mathrm{y}}$ compared by the t-test with Welch criterion, being significant when $\mathrm{p} \leq 0.05$. 
canola hybrids (Hyola 61, Hyola 76, Hyola 433 and Hyola $571 \mathrm{CL}$ ) had higher RC, relative dominance $(\mathrm{K})$ and that the crop is more competitive than the weed (A) when competing with ryegrass. Thus, it was found that there is differentiation in the three indices assessed ( $\mathrm{RC}, \mathrm{K}$ and $\mathrm{A}$ ) only when canola grows with turnip, where hybrid Hyola 433 was more competitive than the others in the presence of this weed. For the same three indices for the crop when it grew with ryegrass there was no differentiation between hybrids when infested with this weed (Table 3).

Therefore it is possible to have tillage programs and choose the canola hybrid to be grown in relation to weeds present in the area, i.e.: if it is turnip, it is better to sow Hyola 433; if it is ryegrass, the possibilities of choice are increased with hybrids Hyola 61, Hyola 76, Hyola 433 and Hyola $571 \mathrm{CL}$. These results reinforce the findings by Bianchi et al. (2006) and Agostinetto et al. (2008), who reported the existence of competitive variability according to the intrinsic characteristics of each cultivar of soybean and rice assessed, respectively. Together with this (crop) tillage is the chemical tillage, where there are several options for the control of grasses (ryegrass) infesting canola and almost nonexistent options for turnip control, because of the botanical similarities that this crop and turnip present so that there are no selective herbicides.

With respect to the three indices assessed to define competitiveness, it was found that forage turnip was more competitive than soybean genotypes (Bianchi et al., 2006) and gulf cockspur grass stood out in relation to irrigated rice (Agostinetto et al., 2008). Nonetheless, Galon et al. (2011) found differentiation regarding barley cultivars (BRS Greta, BRS Elis and BRS 225) when infested by ryegrass.

In most situations, the crop may have greater competitive ability than the weed in isolation, because the weeds effect is not due to their greater individual competition, but mainly to the combined effect of their total plants population (Vilá et al., 2004). However, in some works the weeds have shown greater competitive ability than: irrigated rice versus gulf cockspur grass (Agostinetto et al., 2008) versus red rice (Fleck et al., 2008) and Aeschynomene denticulata (common names vary regionally) (Galon et al., 2015); barley versus ryegrass (Galon et al., 2011); and soybeans versus turnip (Bianchi et al., 2006). It is noteworthy that in a community of plants there is benefit in the competition for resources for those which are established first, or for intrinsic characteristics of each cultivar or hybrids regarding the competitive ability (height, growth rate, number of tillers, leaf area, dry matter, among others); thus, smaller amounts of resources will be available in the environment, which leads to increased damage to the competitor or the crop (Agostinetto et al., 2013).

Jointly interpreting the graphical analysis of relative variables and their significances in relation to the equivalent values (Figures $1,2,3$ and 4), the morphologic variables (Tables 1 and 2) and the competitive indices (Table 3), in general, it was found that there is a negative interaction effect between species, and the canola hybrids are affected, as well as competing weeds (turnip and/or ryegrass). However, in this case, the competing ryegrass suffered major damage than turnip and canola, in particular; only hybrid Hyola 433 was more competitive than turnip, compared with the others. But when all hybrids were compared with ryegrass, they proved to be more competitive than the weed. Thus, differences in terms of competitiveness of assessed species may be due to the fact that these exhibit similar morphological and physiological characteristics in the case of canola and turnip, or exploit the same resources for canola and ryegrass.

By the results obtained in this study, it was found that there is a competition between canola hybrids (Hyola 61, Hyola 76, Hyola 433 and Hyola $571 \mathrm{CL}$ ) in the presence of turnip and/or ryegrass, being adversely affected, irrespective of the plants ratio, in all cases causing reduction in leaf area and dry weight of the species. The competitive ability of canola hybrid Hyola 433 is higher than the one of Hyola 61, Hyola 76 and Hyola 571 CL, when in the presence of turnip. Canola hybrids Hyola 61, Hyola 76, Hyola 433 and Hyola 571 CL have a higher competitive ability than ryegrass. 


\section{ACKNOWLEDGMENT}

To Conselho Nacional de Desenvolvimento Científico e Tecnológico (CNPq; National Counsel of Technological and Scientific Development) and Fundação de Amparo à Pesquisa do Estado do Rio Grande do Sul (FAPERGS; Foundation for Research Support of the Brazilian state of Rio Grande do Sul) for granting the financial aid and scholarship for performing the research.

\section{LITERATURE CITED}

AGOSTINETTO, D. et al. Habilidade competitiva relativa de milhã em convivência com arroz irrigado e soja. Pesq.

Agropec. Bras., v. 48, n. 10, p. 1315-1322, 2013.

AGOSTINETTO, D. et al. Competividade relativa da soja em convivência com papuã (Brachiaria plantaginea). Sci. Agr., v. 10, n. 3, p. 185-190, 2009.

AGOSTINETTO, D. et al. Competitividade relativa entre cultivares de arroz irrigado e biótipo de capim-arroz (Echinochloa spp.). Planta Daninha, v. 26, n. 4, p. 757-766, 2008.

BANDEIRA, T. P.; CHAVARRIA, G.; TOMM, G. O. Desempenho agronômico de canola em diferentes espaçamentos entre linhas e densidades de plantas. Pesq. Agropec. Bras., v. 48, n. 10, p. 1332-1341, 2013.

BIANCHI, M. A.; FLECK, N. G.; LAMEGO, F. P. Proporção entre plantas de soja e plantas competidoras e as relações de interferência mútua. Ci. Rural, v. 36, n. 5, p. 1380-1387, 2006.

COMPANHIA NACIONAL DE ABASTECIMENTO CONAB. Séries históricas de área plantada, produtividade e produção. Disponível em: em: <http:// www.conab.gov.br>. Acesso em: 4 fev. 2015.

COUSENS, R. Aspects of the design and interpretation of competition (interference) experiments. Weed Technol., v. 5, n. 3, p. 664-673, 1991.

COUSENS, R.; O’NEILL, M. Density dependence of replacement series experiments. Oikos, v. 6, n. 2, p. 347-352, 1993.
EMPRESA BRASILEIRA DE PESQUISA AGROPECUÁRIA - EMBRAPA. Centro Nacional de Pesquisa Agropecuária de Solos (Brasília, DF). Sistema brasileiro de classificação de solos. Brasília: Embrapa Produção de Informação; Brasília, DF: Embrapa Solos, 2013. 154 p.

FLECK, N. G. et al. Competitividade relativa entre cultivares de arroz irrigado e biótipo de arroz-vermelho.

Planta Daninha, v. 26, n. 1, p. 101-111, 2008.

GALON, L. et al. Competitividade relativa de cultivares de arroz irrigado com Aeschynomene denticulata. Bragantia, v. 74, n. 1, p. 67-74, 2015.

GALON, L. et al. Habilidade competitiva de cultivares de cevada convivendo com azevém. Planta Daninha, v. 29, n. 4, p. 771-781, 2011.

HOFFMAN, M. L.; BUHLER, D. D. Utilizing Sorghum as a functional model of crop weed competition. I. Establishing a competitive hierarchy. Weed Sci., v. 50, n. 4, p. 466-472, 2002.

LAMEGO, F. P. et al.Habilidade competitiva de cultivares de trigo com plantas daninhas. Planta Daninha, v. 31, n. 3, p. 521-531, 2013.

RIGOLI, R. P. et al. Habilidade competitiva relativa do trigo (Triticum aestivum) em convivência com azevém (Lolium multiflorum) ou nabo (Raphanus raphanistrum). Planta Daninha, v. 26, n. 1, p. 93-100, 2008.

ROUSH, M. L. et al. A comparison of methods for measuring effects of density and proportion in plant competition experiments. Weed Sci., v. 37, n. 2, p. 268-275, 1989.

TAN, X. L. et al. Cloning and analysis of hemoglobin gene in Cyanobacterium and transformation into Brassica napus (L.). Acta Agron. Sinica, v. 35, n. 1, p. 66 70, 2009.

VILÁ, M.; WILLIAMSON, M.; LONSDALE, M. Competition experiments on alien weeds with crops: lessons for measuring plant invasion impact? Biol. Invas., v. 6, n. 1, p. 59-69, 2004.

WOLDEAMLAK, A.; BASTIAANS, L.; STRUIK, P. C. Competition and niche differentiation in barley (Hordeum vulgare) and wheat (Triticum aestivum) mixtures under rainfed conditions in the Central Highlands of Eritrea. J. Agric. Sci., v. 49, n. 1, p. 95-112, 2001. 